\title{
ANALISIS PERUBAHAN KOMPONEN MEDAN MAGNET BUMI PADA SAAT GERHANA MATAHARI TOTAL 9 MARET 2016 di TERNATE
}

\author{
Anton Winarko ${ }^{1, \mathrm{a})}$, Mamat Ruhimat ${ }^{1, \mathrm{~b})}$, Mochamad Andi Aris Biyantoro ${ }^{1, \mathrm{c})}$, \\ Sulimin ${ }^{2}$, Suwardi $^{3}$
}

${ }^{1}$ Pusat Sains Antariksa, LAPAN, Jl. dr. Djundjunan 133 Bandung 40173

${ }^{2}$ Stasiun Meteorologi Kelas I Babullah Ternate, BMKG, Jl. Bandara Ternate 97728

${ }^{3}$ Stasiun Geofisika Kelas III Ternate, BMKG, Jl. Bali Bunga, Ternate Selatan, 97717.

Email: a)anton.winarko@lapan.go.id, ${ }^{\text {b) }}$ mamat.ruhimat@lapan.go.id, ${ }^{\mathrm{c})}$ moh.andi@lapan.go.id

\begin{abstract}
Abstrak
Gerhana Matahari Total (GMT) selain berdampak secara visual, namun juga berdampak pada cuaca antariksa, karena matahari sebagai sumber plasma angin surya yang menggerakkan cuaca antariksa untuk sementara akan terhalang oleh Bulan. Untuk mengetahui pengaruh GMT terhadap medan magnet Bumi, dilakukan pengamatan terhadap variasi harian geomagnet di Ternate sebagai salah satu lokasi totalitas Gerhana Matahari Total 9 Maret 2016, dan dibandingkan dengan keadaan pada hari tenang. Perubahan yang teramati berupa penurunan medan magnet total dan penurunan komponen X, Y dan D sementara pola komponen $\mathrm{Z}$ dan Inklinasi, tidak teramati perubahan yang jelas. Hal ini serupa namun sedikit berbeda dengan studi sebelumnya di lintang tinggi dan menengah, pengaruh GMT terhadap medan geomagnet dikarenakan penurunan tingkat elektron di ionosfer serta penurunan densitas arus ionosfer.
\end{abstract}

Kata-kata kunci: komponen geomagnet, variasi harian geomagnet, Gerhana Matahari Total 2016, Ternate.

\begin{abstract}
Apart from its visual impact, total solar eclipse also has an impact on space weather system as well due to the sun as the source of the solar wind plasma which drives space weather is temporarily obstructed by the Moon. To understand total solar eclipse effect to Earth's magnetic field, observation of the geomagnetic daily variations has been conducted in Ternate as one of the locations of Total Solar Eclipse event on March 9th, 2016, and compared to the condition on a quiet day. Changes is observed as a decrease of the total magnetic field and a decrease in the X, Y and D components while Z and I components seem unclear. This is similar but slightly different with previous studies in the high and middle latitudes, the effect GMT on geomagnetic field due to decreased levels of electrons in the ionosphere as well as a decrease in the current density of the ionosphere.
\end{abstract}

Keywords: Geomagnetic components, geomagnetic daily variations, Total Solar Eclipse of 2016, Ternate.

\section{PENDAHULUAN}

Pada 9 Maret 2016 lalu, sebagian wilayah Indonesia terutama bagian utara mengalami fenomena Gerhana Matahari Total. Saat itu matahari berada pada konstelasi Aquarius. Gerhana diawali sekitar pukul 23.36 UT (08.36 WIT), bergerak dari barat ke sekitar timur laut hingga akhir kontak ke-4 (C4) 
sekitar pukul 11.20 WIT, selanjutnya titik gerhana menjauhi Indonesia dan menuju ke kepulauan sekitar pasifik. Ilustrasi tapak GMT 2016 di Indonesia sebagaimana pada gambar 1-1. Sepasang garis biru tua di bagian tengah adalah jalur totalitas gerhana.

Gerhana matahari selain memberikan dampak visual juga mempengaruhi sistem cuaca antariksa karena aliran plasma dari Matahari sebagai motor sistem cuaca antariksa untuk sementara waktu akan terhalang oleh Bulan. Salah satu yang penting untuk diketahui dan dipahami adalah pengaruhnya terhadap variasi harian medan geomagnet, karena kondisi medan geomagnet akan turut serta mempengaruhi kondisi di ionosfer bahkan litosfer dan sebaliknya [1],[2].

Pada awalnya, pengaruh GMT terhadap medan geomagnet teramati pada penelitian respon arus ionosfer terhadap GMT 31 Agustus 1932. Chapman (1933) mengamati tingkat ionisasi pada lapisan E ionosfer selama $\pm 2,5$ jam totalitas di wilayah Ontario, Kanada. Teramati bahwa tingkat reduksi ionisasi akibat GMT mencapai $60 \%$ dari nilai normalnya. Selain respons di ionosfer tersebut, terdeteksi pula adanya perubahan kecil magnitudo variasi harian medan geomagnet [3].

Medan geomagnet total adalah resultan dari komponen-komponen geomagnet X(utara-selatan), Y (timur-barat), Z (vertikal), serta sudut inklinasi dan deklinasi. Komponen-komponen geomagnet inilah yang menyusun dan mengkarakterisasi variasi harian geomagnet.

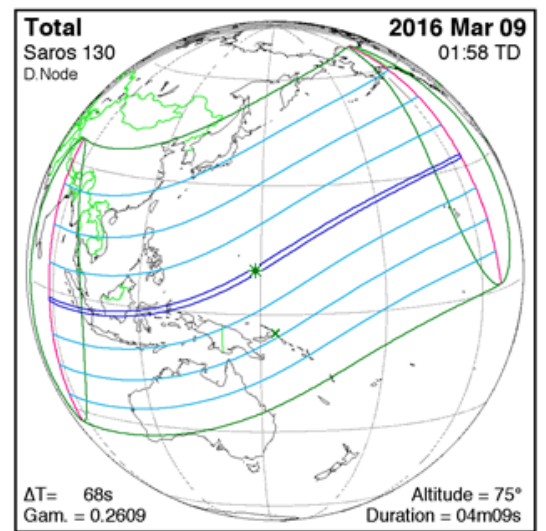

GAMBAR1-1. Jalur GMT 9 Maret 2016 (adaptasi dari http://eclipsewise.com/solar/SEprime/2001-2100/SE2016 Mar09Tprime.html)

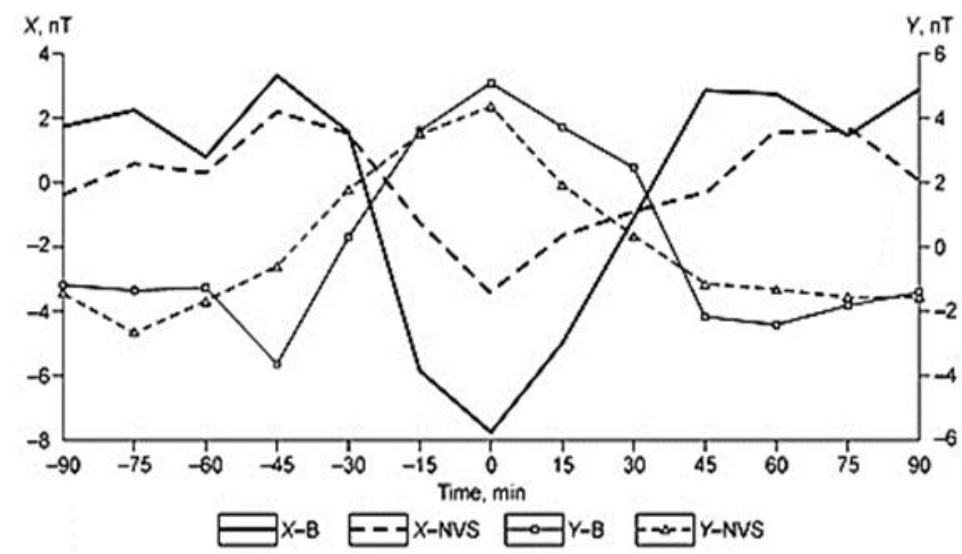




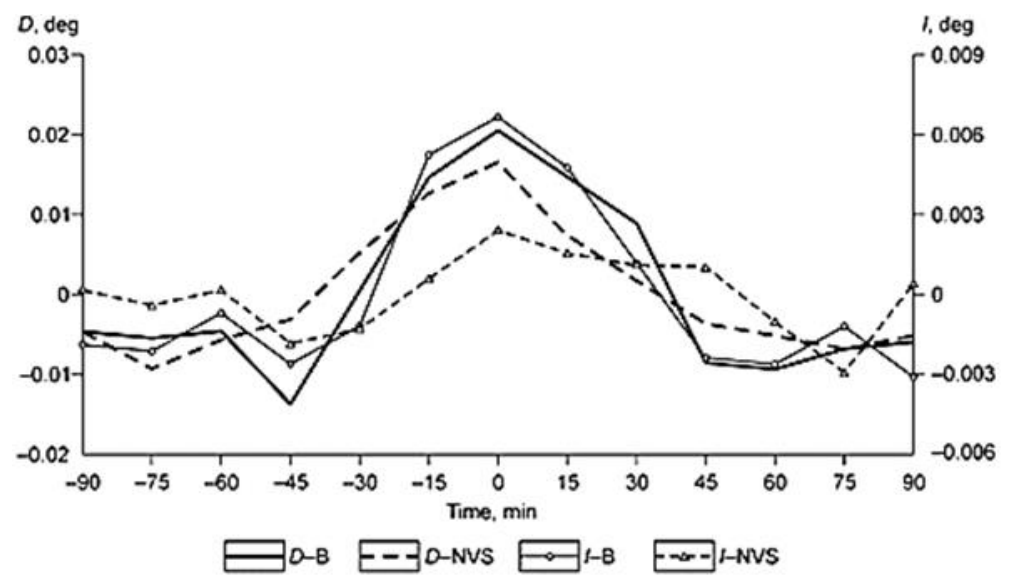

GAMBAR 1-2. Plot perubahan variasi geomagnet saat GMT 1 Agustus 2008 di Novosibirsk (NVS) dan Burmistrovo (B), atas: plot komponen geomagnet X, dan Y; bawah : plot komponen angular. (Ladynin et al, 2011)

Penelitian-penelitian selanjutnya menyimpulkan bahwa variasi harian medan geomagnet dipengaruhi komponen internal dan eksternal [4],[5],[6]. Komponen internal adalah akibat kontribusi gerak plasma inti Bumi, sedangkan komponen eksternal diantaranya berkaitan dengan gerak partikel di atmosfer atas yang menghasilkan gaya gerak listrik dan arus listrik melalui aksi dinamo. Teori dinamo menyatakan bahwa variasi medan magnet Bumi bergantung pada arus listrik di atmosfer atas, dihasilkan oleh pergerakan partikel di medan geomagnet [7]. Berdasarkan eksperimen roket, arus listrik tersebut menjalar terutama di lapisan E ionosfer [8].

Hasil studi pada 2011 meneliti perubahan variasi medan geomagnet di lokasi totalitas GMT 1 Agustus 2008 yaitu Novosibirsk dan Burmistrovo, Rusia menunjukkan bahwa terdapat penurunan signifikan komponen medan geomagnet $\mathrm{X}$ hingga sebesar $-6 \mathrm{nT}$, peningkatan $\mathrm{Y}$ sebesar 1,6 $\mathrm{nT}$ dan peningkatan komponen sudut inklinasi dan deklinasi masing-masing sebesar $0,006^{\circ}$ dan $0,03^{\circ}$ [9]. Plot variasi komponen geomagnet pada saat GMT 1 Agustus 2008 di Novosibirsk dan Burmistrovo sebagaimana gambar 1-2.

Studi yang telah dilakukan pada 2011 tersebut meneliti perubahan pada komponen geomagnet di Rusia saat GMT yang dibandingkan dengan daerah lain di Eropa yang termasuk dalam kategori daerah lintang menengah. Data GMT 2016 yang totalitasnya terjadi di kawasan Indonesia dan pasifik dapat dijadikan sebagai bahan penelitian yang bertujuan untuk mengetahui dan menganalisis perubahan komponen medan geomagnet lokal saat totalitas GMT 2016 terjadi di wilayah Ternate. Sasarannya, dengan diketahuinya tingkat perubahan variasi harian geomagnet, besarnya gangguan geomagnet yang berpotensi mempengaruhi kondisi ionosfer dan litosfer saat GMT terjadi dapat diketahui dan dipahami.

\section{METODE PENELITIAN}

Pengukuran medan geomagnet dilakukan di Ternate (0,89 LU; 127,38 BT) sebagai salah satu daerah totalitas menggunakan magnetometer Gmbh Magson yang disetting dengan resolusi $1 \mathrm{~Hz}$. Data yang digunakan dalam penelitian ini adalah data komponen $\mathrm{X}, \mathrm{Y}$ dan $\mathrm{Z}$ dalam satuan nanoTesla (nT) dari tanggal 4-9 Maret 2016. Interpretasi data dan pengolahan sinyal menggunakan Matlab R2015a. Kontak pertama (C1) terjadi pada 8 Maret 23:36 UT; totalitas terjadi dalam durasi \pm 2 menit 36 detik dimulai sejak kontak kedua pada 9 Maret 00:51 UT dengan totalitas maksimum pada 00:53 UT. 


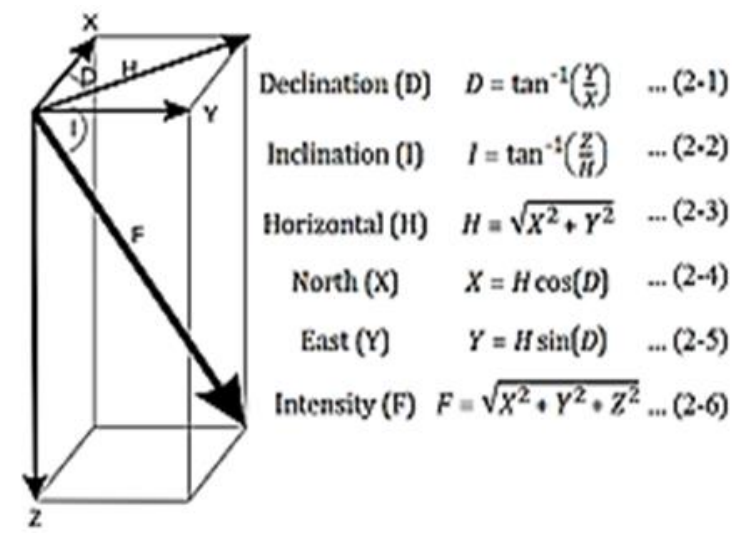

GAMBAR 2-1. Komponen geomagnet yang terdiri atas vektor medan magnet dan sudut

Sebagai data pembanding, digunakan indeks $\mathrm{AE}$, indeks $\mathrm{Kp}$, indeks Dst dan indeks $\mathrm{K}$ lokal. Indeks AE dan Indeks Dst merujuk kepada World Data Center (WDC) kyoto (http://wdc.kugi.kyotou.ac.jp), indeks Kp diperoleh dari IAGA (http://www-app3.gfz-potsdam.de/kp_index/ qlyymm.html), sedangkan indeks K lokal menggunakan data magnetometer stasiun pengamatan Pare-pare.

Komponen inklinasi dan deklinasi diperoleh dengan menggunakan hubungan komponen geomagnet sebagaimana diilustrasikan pada gambar 2-1. Hasil pengukuran dan pengolahan data kemudian diplot dan dianalisis secara visual.

\section{HASIL DAN PEMBAHASAN}

Untuk menentukan kondisi medan geomagnet pada GMT 9 Maret 2016, penting untuk diverifikasi terlebih dahulu faktor kontribusi eksternal dari matahari, sehingga dapat disimpulkan apakah perubahan medan geomagnet disebabkan oleh GMT, ataukah kontribusi dari matahari. Kita dapat meninjau data beberapa indeks geomagnet yang lazim digunakan, yaitu indeks AE, indeks Kp, indeks Dst, serta indeks K.

Sebagai acuan aktivitas geomagnet di daerah polar pada 8 - 9 Maret 2016, kita dapat meninjau indeks AE (Auroral Electrojet) sebagaimana gambar 3-1. Indeks AE adalah indikator masuknya partikel angin matahari ke magnetosfer melalui rekoneksi, yang menyebabkan gangguan geomagnet berupa substorm yang teramati di lintang tinggi/polar [10]. Aktivitas geomagnet sekitar waktu totalitas (C2 pada 00:51 UT - C3 pada 00:54 UT) cenderung tenang, peningkatan aktivitas geomagnet baru terjadi sekitar 2 UT dan 9 UT.

\section{6/03/08-09 AE(11) (Real-Time) woc tor Goomannotism. Kvoto}

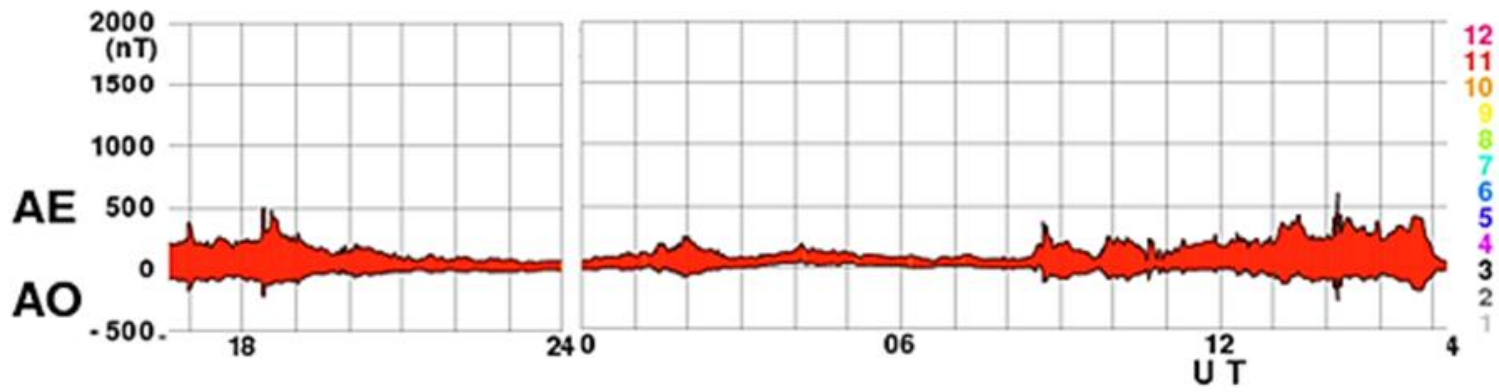

GAMBAR 3-1. Indeks AE pada 8 dan 9 Maret 2016 (http://wdc.kugi.kyoto-u.ac.jp/ae_realtime/201603/ index_20160309.html) 
Untuk gambaran aktivitas di lintang menengah, kita dapat menggunakan indeks Kp [11] sebagaimana Gambar 3-2. Pada gambar 3-3, nampak bahwa pada 9 Maret 2016 nilai indeks Kp maksimum adalah 2, yang masih dalam kategori quiet (tenang).

\begin{tabular}{|c|c|c|c|c|c|c|c|c|}
\hline \multirow[b]{2}{*}{ Day } & \multicolumn{8}{|c|}{ Kp three-hourly } \\
\hline & 1 & 2 & 3 & 4 & 5 & 6 & 7 & 8 \\
\hline 5 & $0+^{(12)}$ & $0+^{(12)}$ & $1+^{(12)}$ & $1++^{(12)}$ & $2-^{(12)}$ & $0++^{(12)}$ & $00^{(12)}$ & $0+^{(12)}$ \\
\hline 6 & $0+(12)$ & $10^{(12)}$ & $20^{(12)}$ & $2 \mathrm{o}^{(12)}$ & $2+(12)$ & $5-(12)$ & $6-^{-(12)}$ & $6+^{(12)}$ \\
\hline 7 & $5-(12)$ & 5- & $3+$ & $2+$ & $3-$ & $3+$ & $3+$ & 40 \\
\hline 8 & $3-$ & 20 & $2-$ & $2-$ & 20 & $1+$ & 20 & $1-$ \\
\hline 9 & $2-$ & 20 & $1+$ & $1+$ & $2-$ & $1+$ & 10 & $2-$ \\
\hline 10 & ${ }^{n_{+}}$ & $9+$ & ?- & $1+$ & 1n & 1n & ?- & $9_{+}$ \\
\hline
\end{tabular}

GAMBAR 3-2. Indeks Kp pada 5 - 9 Maret 2016 (sumber : http://www-app3.gfz-potsdam.de/ kp_index/ qlyymm.html)

Sedangkan untuk indikator keadaan geomagnet di Indonesia, kita bisa menggunakan indeks Dst atau indeks $\mathrm{K}$ lokal sebagaimana gambar 3-3a dan 3-3b. Gambar 3-4 menunjukkan bahwa terjadi badai geomagnet pada tanggal 6 Maret 2016, yang selanjutnya mengalami masa recovery. Jika kita meninjau indeks $\mathrm{K}$, nampak bahwa berangsur-angsur terjadi penurunan aktivitas geomagnet pada tanggal 7 Maret 2016 hingga mencapai nilai indeks K 0 pada 8 Maret 2016 sehingga kita dapat menginterpretasikan bahwa fase recovery berakhir dan pada tanggal 9 Maret 2016, aktivitas geomagnet relatif tenang.

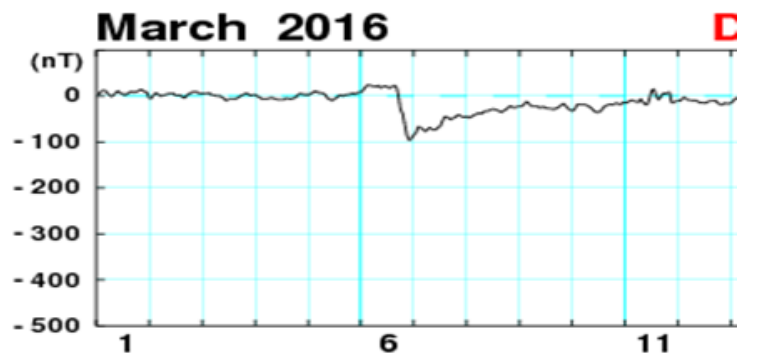

GAMBAR 3-3a. Indeks Dst (sumber indeks Dst: http://wdc.kugi.kyoto-u.ac.jp/dst_realtime/201603/index.html)

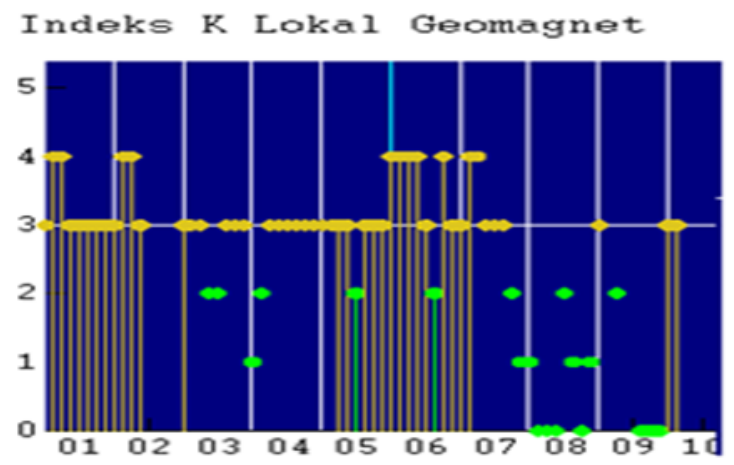

GAMBAR 3-3b. Indeks K lokal geomagnet.

Berdasarkan indeks $\mathrm{AE}$, indeks $\mathrm{Kp}$, indeks Dst dan indeks $\mathrm{K}$ lokal, dapat disimpulkan bahwa kondisi geomagnet pada 9 Maret 2016 relatif tenang, sehingga kontribusi gangguan dari Matahari dapat diabaikan dalam pengamatan komponen variasi harian geomagnet saat GMT terjadi. 


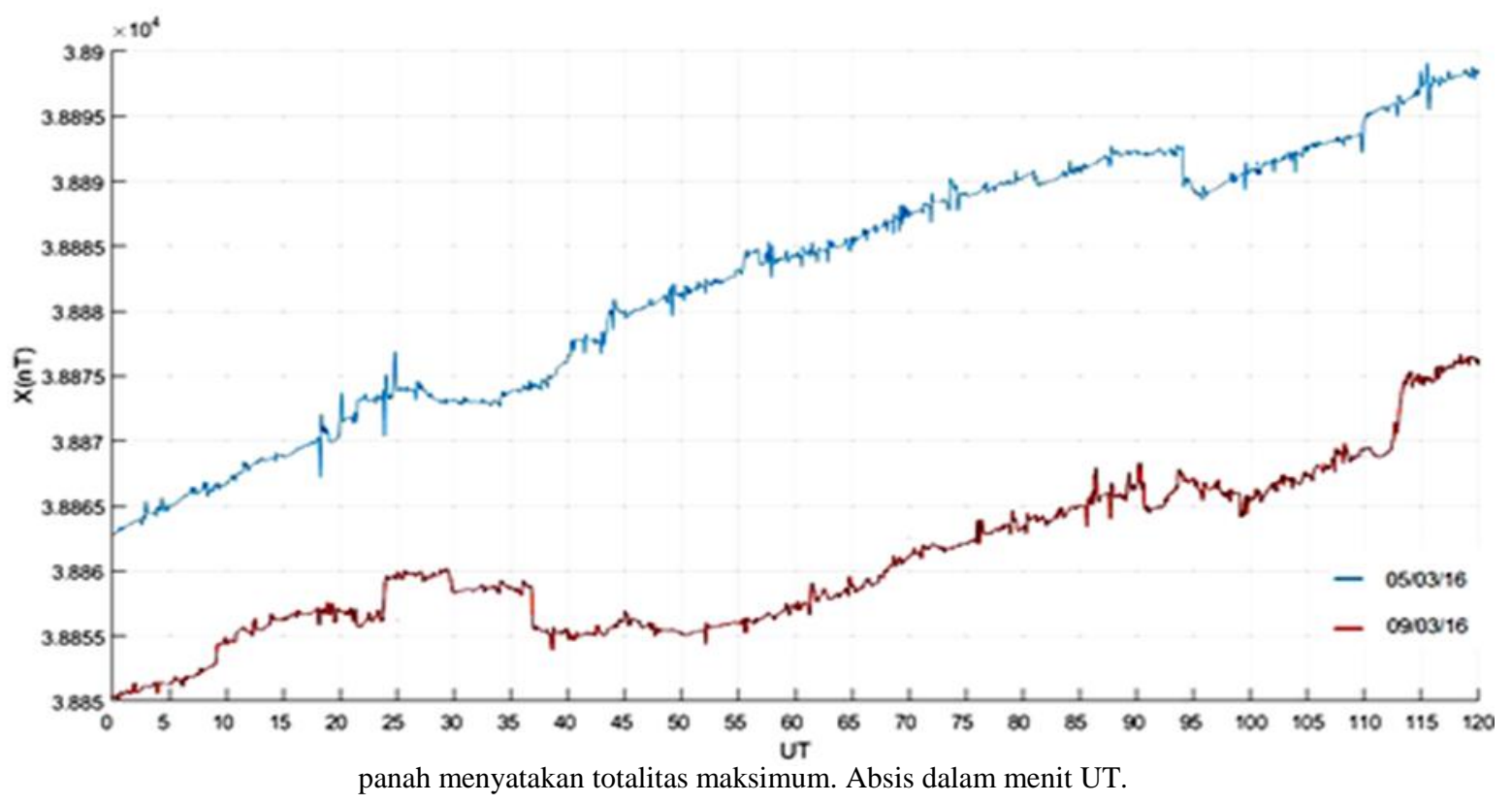

Gambar 3-4 menunjukkan adanya penurunan komponen $\mathrm{X}$ beberapa saat sebelum kontak kedua GMT 9 Maret 2016 (saat seluruh permukaan Matahari mulai tertutup Bulan, ditandai pula dengan kemunculan Baily's Beads). Dibandingkan dengan pola pada tanggal 5 Maret yang dipilih sebagai hari tenang, variasi harian pada 9 Maret 2016 secara umum lebih terganggu. Penurunan signifikan terjadi pada menit ke-38 sebesar $\pm 5 \mathrm{nT}$, pola komponen pada saat tersebut menyimpang dari trendnya dan berbeda dengan keadaan pada 5 Maret 2016.

Dalam studi variasi diurnal geomagnet, komponen $\mathrm{Y}$ memegang peranan penting karena komponen tersebut memiliki pola yang paling regular dibandingkan $\mathrm{X}$ atau $\mathrm{Z}$ [12]. Gambar 3-5 menunjukkan plot komponen Y pada sekitar waktu totalitas gerhana. Waktu perubahan yang terjadi tidak jauh berbeda dengan perubahan komponen X. Pola hingga menit ke-40 tampak serupa dengan hari tenang namun dengan kurva kenaikan yang lebih curam, diikuti dengan penurunan sekitar $4 \mathrm{nT}$ selama 20 menit setelahnya,

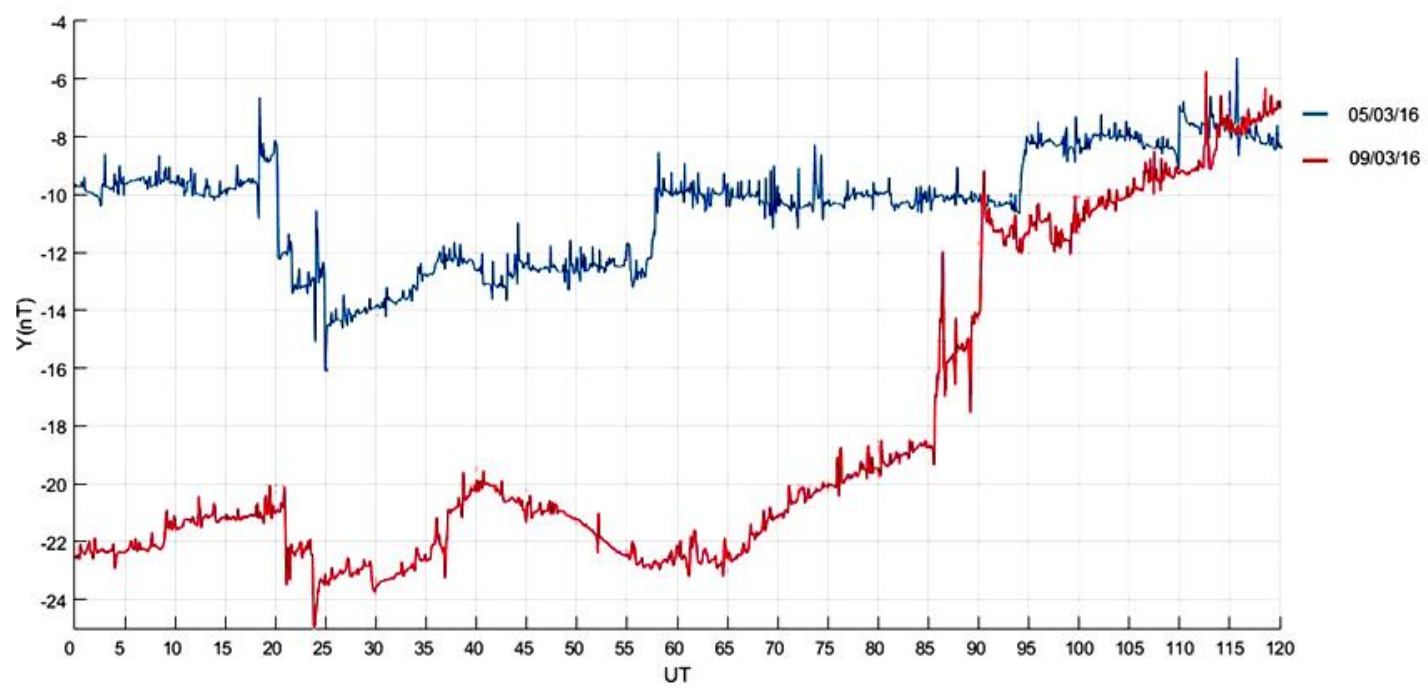

GAMBAR 3-5. Plot komponen Y medan geomagnet pada tanggal 5 dan 9 Maret 2016 pukul $00.00-02.00$ UT. Tanda panah menyatakan totalitas maksimum. Absis dalam menit UT. 
Komponen D (sudut deklinasi antara utara geografis dan utara magnetik) diturunkan berdasarkan hubungan (2-1) memiliki pola yang serupa dengan Y. Menggunakan hubungan (2-1) tersebut, didapat penurunan deklinasi hingga $0.005^{\circ}$, artinya pada saat GMT, utara magnetik cenderung semakin menjauhi utara geografis ke arah barat.

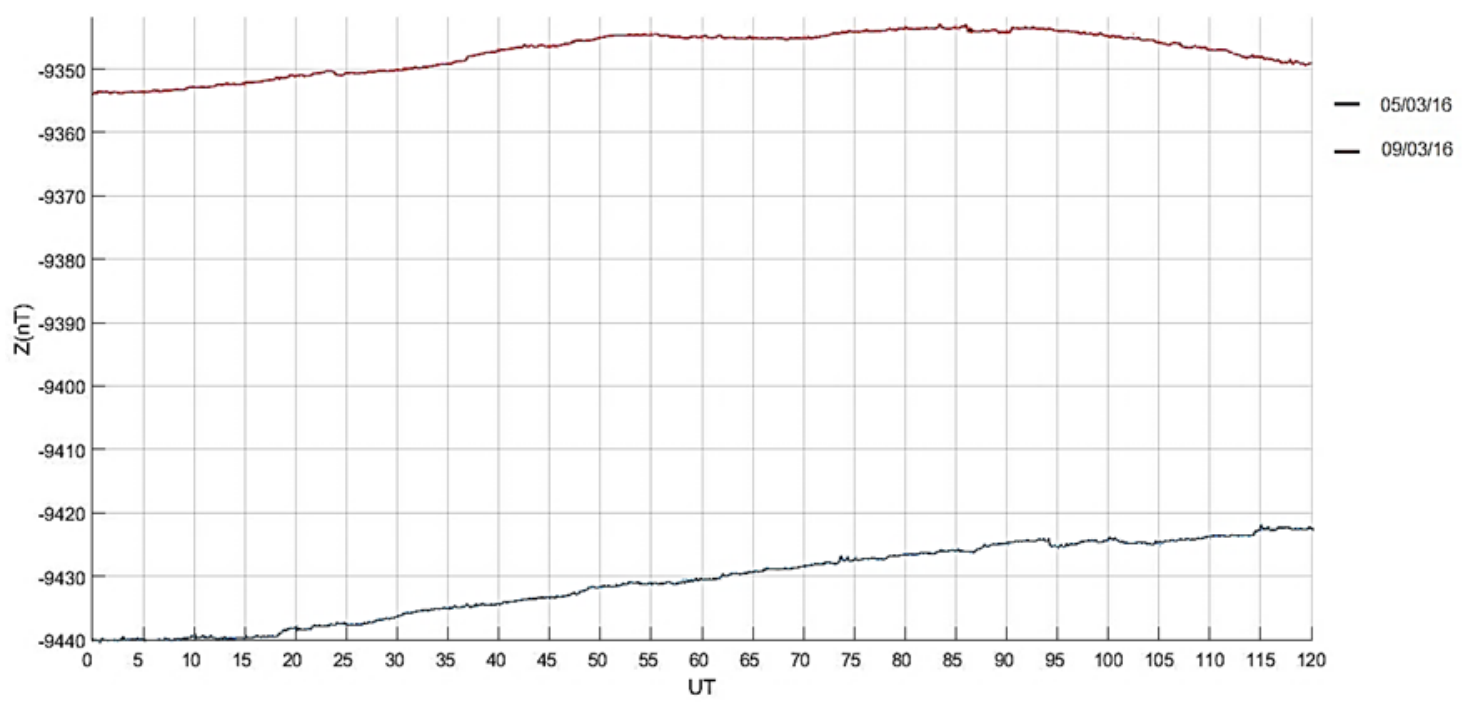

GAMBAR 3-6. Plot komponen $\mathrm{Z}$ medan geomagnet pada tanggal 5 dan 9 Maret 2016 pukul $00.00-02.00$ UT. Absis dalam menit UT.

Sementara berdasarkan gambar 3-6, tampak bahwa perubahan komponen vertikal Z (dan inklinasi yang diturunkan berdasarkan hubungan (2-2) pada bab pendahuluan) saat GMT tidak terlihat jelas dan tidak begitu berbeda dibandingkan dengan hari tenang. Nilai $\mathrm{Z}$ negatif berarti medan magnetik secara vertikal cenderung mengarah ke atas.

Hasil-hasil yang didapat ini serupa dengan studi sebelumnya di lintang menengah yang menghasilkan kesimpulan adanya penurunan signifikan komponen medan geomagnet $\mathrm{X}$, peningkatan Y dan peningkatan komponen sudut inklinasi dan deklinasi [9].

Beberapa studi sebelumnya yang menggunakan data kelistrikan atmosfer/ionosfer menyimpulkan bahwa perubahan atas komponen geomagnet yang terjadi saat peristiwa GMT disebabkan oleh penurunan konsentrasi elektron di ionosfer yang memicu penurunan tingkat arus ionosfer sehingga berpengaruh pada medan magnet Bumi [9],[13],[14].

\section{SIMPULAN}

Dari pengamatan yang telah dilakukan, dapat ditarik kesimpulan bahwa sebagai respons pada saat GMT 2016 di wilayah Ternate, medan geomagnet mengalami perubahan yang dimulai beberapa saat sebelum kontak kedua (00:51:43 UT) yaitu penurunan komponen $\mathrm{X}$ sebesar $\sim 5 \mathrm{nT}$, peningkatan komponen Y sekitar $4 \mathrm{nT}$ serta pergeseran deklinasi sebesar $-0,005^{\circ}$. Hasil ini serupa dengan studi sebelumnya di lintang menengah yang mendeteksi adanya penurunan komponen $\mathrm{X}$, peningkatan $\mathrm{Y}$, serta peningkatan inklinasi dan deklinasi. Perubahan komponen geomagnet saat peristiwa GMT disebabkan oleh penurunan konsentrasi elektron di ionosfer yang memicu penurunan tingkat arus ionosfer sehingga berpengaruh pada medan magnet Bumi.

\section{UCAPAN TERIMAKASIH}

Penulis mengucapkan terima kasih kepada Kepala Pusat Sains Antariksa LAPAN, Stasiun BMKG Ternate, serta kepada rekan penulis yaitu Farahhati Mumtahana dan Cucu Eman Haryanto atas segala bantuannya dalam pengolahan data dan penyusunan makalah ini. 


\section{DAFTAR ACUAN}

[1] Thébault, E., Purucker, M., Kathryn, The Magnetic Field of Earth's Litosphere, Space Sci Rev. 155:95-127, 2010.

[2] Love, J. J., Swidinsky, A., Time Causal Operational Estimation of Electric Fields Induced in the Earth's Lithosphere During Magnetic Storms, Geophys. Res. Lett., 41, doi:10.1002/2014GL059568, 2014.

[3] Chapman,S., The Effect of Solar Eclipse on the Earth's Magnetic Field, Imperial College of Science and Technology, South Kensington London, England, vol 38 no. 3, 1933, pp. 175-183.

[4] Matsushita, S. and Maeda, H., On the Geomagnetic Solar Quiet Daily Variation Field During the IGY, J. Geoph. Res. vol 70 no 11, 1965.

[5] Malin, S. R. C., Isikara, A. M., Annual Variation of the Geomagnetic Field, Geophys. J. R. astr. Soc. p.47, 1976, pp.445-457.

[6] Gavoret, J., Gibert, D., Menvielle, M., Le Mouel, J.L., Long-Term Variations of the External and Internal Components of the Earth's Magnetic Field, J. Geoph. Res. 90-B5, 1986, pp. 4787-4796.

[7] Torta, J. M., Marsal, S., Curto, J.C., Gaya-Pique, L. R., Behaviour of the Quiet-day Geomagnetic Variation at Livingstone Island and Variability of the Focus Position in the South American-Antarctic Peninsula Region. Earth Planets Space, 62, 2010, pp. 297-307.

[8] Singer, S. Fred, E. Maple, W.A Bowen Jr., Evidence For Ionospheric Currents From Rocket Experiments Near the Geomagnetic Equator, J. Geophys. Res., 56(2), 1951, pp. 265-281.

[9] Ladynin, A.V., Semakov, N. N., Khomutov, S. Y., Changes in the Daily Geomagnetic Variation During the Total Solar Eclipse of 1 August 2008, Russian Geology and Geophysics, 52, 2011, pp. 343-352.

[10] Nakamura, M., Yoneda, A., Oda, Tsubouchi, K.., Statistical analysis of extreme auroral electrojet indices, Earth Planet Space 67: 153, 2015.

[11] Park, M. Y., Lee, D. Y., Shin, D. K., Cho, J. H., Lee, E. H., Dependence of Energetic Electron Precipitation on the Geomagnetic Index Kp and Electron Energy, J. Astron. Space Sci. 30(4), 2013, pp. 247-253.

[12] Curto, J.J, Heilig, B., Pino, M., Modelling the Geomagnetic Effects Caused by the Solar Eclipse of 11 August 1999, J. Geophys. Res. 111. A07312, doi:10.1029/2005JA011499, 2006.

[13] Babakhanov, I.Y., Belinskaya, A.Y., Bizin, M.A., Grekhov, O. M., Khomutov, S.Y., Kuznetsov, V.V., Pavlov, A.P.,. The Geophysical Disturbances during the Total Solar Eclipse of 1 August 2008 in Novosibirsk, Russia, J. Atmospheric and Solar- $\quad$ Terrestrial Physics, 92, 2013, pp. 1-6.

[14] Kumar, K. V., Maurya, A. K., Kumar, S., \& Singh, R., 22 July 2009 total solar eclipse induced gravity waves in ionosphere as inferred from GPS observations over EIA, Advances in Space Research, DOI : 10.1016/j.asr.2016.07.019, 2016.

[15] http://eclipsewise.com/solar/SEprime/2001-2100/ SE2016Mar09Tprime.html, diakses tanggal 15 Maret 2016.

[16] http://www-app3.gfz-potsdam.de/kp_index/qlyymm .html, diakses tanggal 15 Maret 2016.

[17] http://wdc.kugi.kyoto-u.ac.jp/dst_realtime/201603/ index.html, diakses tanggal 1 April 2016.

[18] http://wdc.kugi.kyoto-u.ac.jp/ae_realtime/201603/ index_20160309.html, diakses tanggal 12 April 2016. 